\section{Discussion}

Scleroderma of the lung ${ }^{1}$ and the proximal muscles ${ }^{2}$ has been well described but not, to our knowledge, scleroderma of the diaphragm. Diaphragmatic symptoms have been described in systemic lupus erythematosus, ${ }^{3}$ but the clinical picture and low level of anti-DNA antibody and the findings at necropsy militate against a diagnosis of this or of mixed connective tissue disease. The raised activity of creatinine phosphokinase in this patient suggest that the myopathy may have fitted into the pattern of inflammatory myopathy, ${ }^{4}$ which might, therefore, have responded to treatment with corticosteroids. We suggest that the extensive fibrosis with accompanying degeneration of the myofibrils within skeletal type muscle in the diaphragm (figure) was secondary to scleroderma and a contributing factor to the terminal respiratory failure. Diaphragmatic changes should, therefore, be added to the list of respiratory complications in scleroderma.
We thank Ms P Elphick for secretarial help.

Requests for reprints should be addressed to Dr Gerald D Iliffe, Room GC425, Health Sciences Centre, 700 William Avenue, Winnipeg, Manitoba, Canada R3E 0Z3.

\section{References}

${ }^{1}$ Bader RA, Bader ME. Thoracic manifestations of collagen diseases. In: Baum GL, ed. Textbook of pulmonary disease. 2nd ed. Boston: Little, Brown and Co, 1974:463-7.

2 Rodnan GP. Progressive systemic sclerosis (scleroderma). In: Hollander JL, McCarty DJ Jr, eds. Arthritis and allied conditions. Philadelphia: Lea and Febiger, 1972:962-1005.

${ }^{3}$ Gibson GJ, Edmonds JP, Hughes GRV. Diaphragm function and lung involvement in systemic lupus erythematosus. Am $\mathcal{F}$ Med 1977 63:926-32.

4 Clements PJ, Furst DE, Campion DS, et al. Muscle disease in progressive systemic sclerosis. Arthritis Rheum 1978;21:62-71.

(Accepted 23 November 1982)

\title{
HLA antigens and acetylcholine receptor antibodies in penicillamine induced myasthenia gravis
}

\author{
MICHAEL J GARLEPP, ROGER L DAWKINS, FRANK T CHRISTIANSEN
}

\begin{abstract}
Antibodies to the acetylcholine receptor and HLA antigens have been studied in patients with myasthenia gravis occurring in association with penicillamine treatment. The properties of the antiacetylcholine receptor in these patients differed from those in patients with idiopathic myasthenia gravis in terms of specificity and affinity. These patients had an increased prevalence of HLA Bw35 and DR1 compared to controls and a decreased frequency of $B 8$ and DR3 compared to patients with idiopathic myasthenia gravis. Likewise, they had a decreased frequency of DR4 compared to patients with rheumatoid arthritis.

These data provide supportive evidence for a role for penicillamine in the induction of myasthenia gravis in genetically predisposed individuals.
\end{abstract}

\section{Introduction}

For many years penicillamine has been used in the treatment of rheumatoid arthritis. The drug has been implicated in the induction of several autoimmune diseases, including myasthenia gravis. ${ }^{1}$ The myasthenia gravis induced by penicillamine is clinically indistinguishable from idiopathic myasthenia gravis and is invariably associated with the presence of antibodies to the acetylcholine receptor. After withdrawal of penicillamine, titres of antiacetylcholine receptor usually fall and myasthenia gravis resolves. ${ }^{1}$

The aetiological agent in idiopathic myasthenia gravis is unknown. In Caucasians the HLA antigens B8 and DR3 are known to be increased, particularly in those patients with early onset of disease and thymic hyperplasia. ${ }^{2}{ }^{3} \mathrm{By}$ contrast there is

Department of Clinical Immunology, Royal Perth Hospital, Perth, Western Australia 6000 and Department of Pathology, University of Western Australia

MICHAEL J GARLEPP, BSC, scientific officer

ROGER L DAWKINS, MD, FRACP, head of department

FRANK T CHRISTIANSEN, FRACP, FRCPA, clinical immunologist an increase in the prevalence of DR4 in patients with rheumatoid arthritis. $^{4}$

We have previously reported that antiacetylcholine receptor in patients with penicillamine induced myasthenia gravis is less cross reactive than that from patients with idiopathic myasthenia gravis. ${ }^{5}$ Antiacetylcholine receptor in penicillamine induced myasthenia gravis tends to have a higher average affinity (see below). These data suggest that penicillamine induced myasthenia gravis is subtly different from the idiopathic disease and support the conclusion that penicillamine may induce myasthenia gravis.

The identification of genetic factors that predispose to the induction of myasthenia gravis by penicillamine would provide further such evidence. More importantly, the identification of a susceptible genetic background, combined with the knowledge of the aetiological agent, would provide a unique opportunity to study the pathogenesis of myasthenia gravis.

In a preliminary report we noted that Caucasian patients with penicillamine induced myasthenia gravis have a higher than expected prevalence of Bw35 and DR $1 .{ }^{6}$ We now present the full typing data and compare prevalences of HLA types in these patients with those in patients with rheumatoid arthritis, patients with idiopathic myasthenia gravis, and controls.

\section{Patients and methods}

Clinical details and sera were supplied by several clinicians throughout Australia, New Zealand, United Kingdom, and the United States of America. All but two patients were being treated for rheumatoid arthritis. One of the exceptions was receiving penicillamine for scleroderma ${ }^{7}$ and the other for Wilson's disease. ${ }^{8}$ All were Caucasian.

Tissue typing was performed using standard microlymphocytotoxicity techniques. ${ }^{9}$ Typing was done in the patients' own area and the HLA types supplied by their clinicians. Details on 12 patients were collected by this laboratory. These have been combined with details of four cases whose HLA data and antiacetylcholine receptor titre have been published by others. ${ }^{710-12}$ All 16 patients were typed for HLA-A and HLA-B antigens and 10 of these were also typed for DR.

Since the patients were derived from several centres throughout the world an appropriate control group was difficult to obtain. Antigen prevalences have been compared with those found in healthy Cauca- 
sians in the Second Asia Oceania Histocompatibility Workshop Conference and Caucasian patients with rheumatoid arthritis who were typed for HLA antigens in this laboratory for the Second Asia Oceania Histocompatibility Workshop Conference. Statistical comparisons were made using the binomial test taking the prevalences of phenotypes in the comparison groups as the probabilities of occurrence of particular antigens.

Antiacetylcholine receptor was measured in 43 patients with penicillamine induced myasthenia gravis by previously published methods and titres were expressed in arbitrary units. ${ }^{13}$ Antiacetylcholine receptor affinity was determined by the method of Odell et al. ${ }^{14}$ A standard volume of serum $(5 \mu \mathrm{l})$ was reacted against increasing concentrations of acetylcholine receptor and precipitated with goat antihuman IgG. ${ }^{13}$ IgG present in the crude preparations of acetylcholine receptor was routinely removed by passage through Sepharose anti-IgG columns (Garlepp et al, unpublished observations). In excess of acetylcholine receptor a plateau of binding was reached and the average affinity of the antiacetylcholine receptor was determined from the reciprocal of the free concentration of acetylcholine receptor at $50 \%$ saturation (fig 1). This technique was preferred to Scatchard analysis, which is best applied to systems in which there is noncooperative binding of univalent ligands of homogeneous affinity to their receptors. ${ }^{14}$

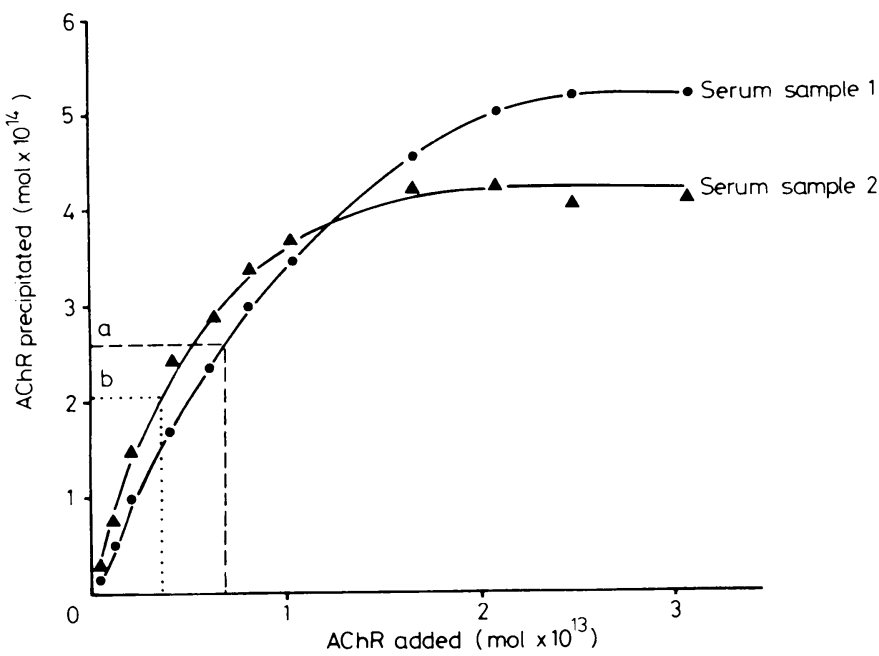

FIG 1-Determination of binding affinity of antiacetylcholine receptor (AChR). Points $a$ and $b$ represent $50 \%$ antibody saturation for serum samples 1 and 2 respectively: free concentration at these points may be calculated, by subtraction, from the AChR added.

\section{Results}

\section{ANTIACETYLCHOLINE RECEPTOR}

Figure 2 shows titres of antiacetylcholine receptor in patients with penicillamine induced myasthenia gravis. All four patients who had titres $<1$ unit were in remission at the time of assay.

Table I shows the average binding affinities and titres of antiacetylcholine receptor in patients with idiopathic $(n=14)$ and penicillamine induced $(\mathrm{n}=11)$ myasthenia gravis. Patients with penicillamine induced disease had higher affinities $(p=0.025$; MannWhitney U test).

\section{HLA TYPES}

Table II shows the HLA types of 16 patients with penicillamine induced myasthenia gravis. Table III shows the prevalences of selected antigens in these patients compared with their prevalences in patients with idiopathic myasthenia or rheumatoid arthritis and those in Caucasian controls.

Prevalences of Bw35 and DR1 and of the combination Bw35 and DR1 were increased in patients with penicillamine induced myasthenia gravis compared to patients in all other groups. By contrast prevalences of $\mathrm{B} 8$ and DR3 and the combination A1, B8, DR3 were increased in patients with idiopathic myasthenia gravis and DR4 was increased in patients with rheumatoid arthritis.

\section{Discussion}

These results show that although penicillamine induced and idiopathic myasthenia gravis are both associated with antiacetylcholine receptor and are clinically identical they do differ in some respects.

We have previously reported that antiacetylcholine receptor from patients with penicillamine induced disease show only

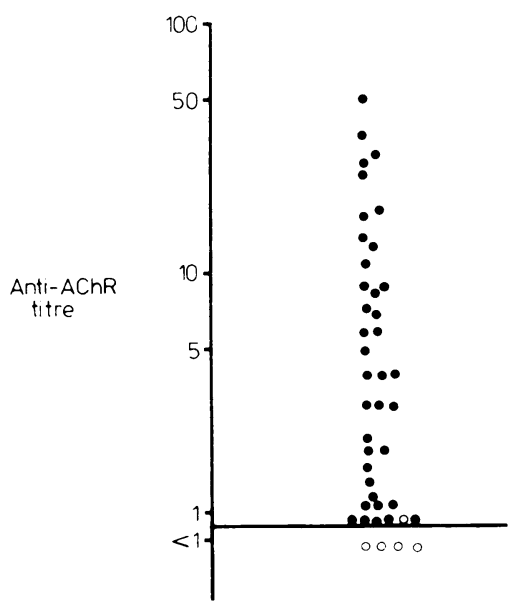

FIG 2-Titres of antiacetylcholine receptor $(\mathrm{AChR})$ in 43 patients with penicillamineinduced myasthenia gravis. $\mathrm{O}=$ Patient in remission.

TABLE I-Affinities of antiacetylcholine receptor in serum from patients with myasthenia gravis

\begin{tabular}{|c|c|c|c|c|c|}
\hline \multicolumn{3}{|c|}{ Idiopathic } & \multicolumn{3}{|c|}{ Penicillamine induced } \\
\hline $\begin{array}{l}\text { Case } \\
\text { No }\end{array}$ & $\begin{array}{c}\text { Titre } \\
\text { (units) }\end{array}$ & $\begin{array}{c}\text { Affinity } \\
\left(1 / \mathrm{mol} \times 10^{10}\right)\end{array}$ & $\begin{array}{l}\text { Case } \\
\text { No }\end{array}$ & $\begin{array}{c}\text { Titre } \\
\text { (units) }\end{array}$ & $\underset{\left(1 / \mathrm{mol} \times 10^{10}\right)}{\text { Affinity }}$ \\
\hline $\begin{array}{r}1 \\
2 \\
3 \\
4 \\
5 \\
6 \\
7 \\
8 \\
9 \\
10 \\
11 \\
12 \\
13 \\
14\end{array}$ & $\begin{array}{r}80 \\
22 \\
180 \\
25 \\
2100 \\
12 \\
47 \\
250 \\
12 \\
25 \\
43 \\
100 \\
25 \\
22\end{array}$ & $\begin{array}{c}7 \cdot 8 \pm 0 \cdot 3 * \\
5 \cdot 9 \pm 0 \cdot 5 \\
5 \cdot 7 \pm 0 \cdot 8 \\
5 \cdot 3 \pm 1 \cdot 0 \\
5 \cdot 1 \\
4 \cdot 5 \pm 0 \cdot 5 \\
4 \cdot 3 \pm 0 \cdot 8 \\
4 \cdot 1 \pm 1 \cdot 0 \\
3 \cdot 2 \pm 0 \cdot 1 \\
2 \cdot 6 \\
2 \cdot 3 \\
2 \cdot 1 \\
<1 \cdot 3 \\
<0.7\end{array}$ & $\begin{array}{l}15 \\
16 \\
17 \\
18 \\
19 \\
20 \\
21 \\
22 \\
23 \\
24 \\
25\end{array}$ & $\begin{array}{r}2 \\
25 \\
9 \\
9 \\
36 \\
17 \\
13 \\
8 \\
9 \\
15 \\
5\end{array}$ & $\begin{array}{c}11 \cdot 6 \pm 0.9 * \\
9.9 \pm 1 \cdot 1 \\
8 \cdot 6 \pm 0 \cdot 9 \\
8 \cdot 3 \\
8 \cdot 0 \pm 1 \cdot 2 \\
7 \cdot 0 \\
5 \cdot 5 \\
4 \cdot 8 \\
2.9 \pm 0 \cdot 4 \\
2 \cdot 7 \\
<0.9\end{array}$ \\
\hline Mea & & $3.9 \pm 1.9$ & & & $6 \cdot 4 \pm 3 \cdot 2$ \\
\hline
\end{tabular}

* Mean of 2-5 experiments where $\mathrm{SD}$ is shown

TABLE II-Clinical details of 16 patients with penicillamine induced myasthenia gravis*

\begin{tabular}{|c|c|c|c|c|c|c|}
\hline \multirow{2}{*}{ Case No } & \multirow{2}{*}{ Age } & \multirow{2}{*}{ Sex } & \multirow{2}{*}{ Anti-AChR } & \multicolumn{3}{|c|}{ HLA type } \\
\hline & & & & A & B & DR \\
\hline $\begin{array}{l}15 \\
17 \\
20 \\
21 \\
22 \\
23 \\
24 \\
26 \\
27 \\
28 \\
29 \\
30 \\
31 \\
32 \\
33 \\
34\end{array}$ & $\begin{array}{c}52 \\
39 \\
65 \\
24 \\
64 \\
\text { NA } \\
21 \\
42 \\
70 \\
\text { NA } \\
\text { NA } \\
\text { NA } \\
\text { NA } \\
48 \\
34 \\
52\end{array}$ & $\begin{array}{l}F \\
F \\
F \\
F \\
F \\
F \\
F \\
F \\
F \\
F \\
M \\
F \\
F \\
F \\
F \\
F\end{array}$ & $\begin{array}{l}+ \\
+ \\
+ \\
+ \\
+ \\
+ \\
+ \\
+ \\
+ \\
+ \\
+ \\
+ \\
+ \\
+ \\
+ \\
+\end{array}$ & $\begin{array}{c}2,3 \\
1,2 \\
1,2 \\
11, w 24 \\
3,11 \\
1,11 \\
1 \\
3,11 \\
3, w 24 \\
2,23 \\
1,3 \\
1,3 \\
2,3 \\
\text { w31, w32 } \\
1 \\
3,11\end{array}$ & $\begin{array}{c}7,27 \\
8,18 \\
\text { w35, 40 } \\
27, \text { w35 } \\
7 \\
8, \text { w35 } \\
14,37 \\
\text { w35 } \\
\text { 18, w35 } \\
7, \text { w49 } \\
\text { w35, w57 } \\
7,8 \\
\text { w35, w39 } \\
\text { 27, w44 } \\
5,8 \\
\text { w35 }\end{array}$ & $\begin{array}{c}2, \text { w6 } \\
2,7 \\
1, w 6 \\
\text { NA } \\
1 \\
1,3 \\
\text { NA } \\
\text { NA } \\
1, \text { w6 } \\
1,4 \\
1,7 \\
\text { NA } \\
5, \text { w8 } \\
\text { NA } \\
\text { NA } \\
1,8\end{array}$ \\
\hline
\end{tabular}

$\mathrm{AChR}=$ Acetylcholine receptor. $\mathrm{NA}=$ Not available.

*Cases $21,24,32,33$, and 34 were reported in references $7,8,11,10$, and 12 respectively. 
TABLE III-Prevalence of HLA antigens in patients with penicillamine induced myasthenia gravis compared to that in patients with idiopathic myasthenia gravis or rheumatoid arthritis and in controls. Figures are numbers (\%) of patients

\begin{tabular}{|c|c|c|c|c|}
\hline & $\begin{array}{l}\text { Drug induced } \\
\text { myasthenia gravis } \\
\qquad(\mathrm{n}=16)\end{array}$ & $\begin{array}{l}\text { Rheumatoid } \\
\text { arthritis } \\
(\mathrm{n}=52)\end{array}$ & $\begin{array}{c}\text { Idiopathic } \\
\text { myasthenia gravis } \\
(\mathrm{n}=35)\end{array}$ & $\begin{array}{l}\text { Controls* } \\
(\mathrm{n}=108)\end{array}$ \\
\hline \multicolumn{5}{|c|}{$A$ and $B$ types } \\
\hline $\begin{array}{l}\text { A1 } \\
\text { A11 } \\
\text { B8 } \\
\text { Bw35 }\end{array}$ & $\begin{array}{l}7(44) \\
5(31) \\
4(25) \\
8(50)+\end{array}$ & $\begin{array}{c}20(38) \\
7(13) \\
18(36) \\
8(15) \dagger\end{array}$ & $\begin{aligned} 22 & (64) \\
2 & (6) \\
19 & (54) \\
5 & (14)+\end{aligned}$ & $\begin{array}{c}45(42) \\
8(7) \\
30(28) \\
12(11)+\end{array}$ \\
\hline \multicolumn{5}{|c|}{$D R$ types +} \\
\hline $\begin{array}{l}\text { DR1 } \\
\text { DR3 } \\
\text { DR4 } \\
\text { Bw35/DR1 } \\
\text { A1/B8/DR3 }\end{array}$ & $\begin{array}{l}7(70) \S \\
1(10) ! \\
1(10) \dagger \\
5(50) \\
1(10)\end{array}$ & $\begin{array}{c}9(20) \S \\
10(23) \\
30(67) \dagger \\
2(5) \\
5(11)\end{array}$ & $\begin{aligned} 7 & (20) \S \\
16 & (46) \\
7 & (20) \\
1 & (3) \\
16 & (46)\end{aligned}$ & $\begin{array}{c}19(18) \S \\
25(23) \\
35(32) \\
5(5) \\
19(18)\end{array}$ \\
\hline
\end{tabular}

* Controls taken from cases reported at Second Asia Oceania Histocompatibility Workshop.

$+\mathrm{p}<0 \cdot 005$. myasthenia gravis and in 44 of the 52 with rheumatoid arthritis. $\$ \mathrm{p}<0.001$.

limited cross reactivity with xenogeneic acetylcholine receptor. ${ }^{5}$ This lack of cross reactivity is not merely due to inadequate test concentrations of acetylcholine receptor or to short incubation times as has been suggested. ${ }^{15}$ Using Scatchard analysis Vincent and Newsom-Davis ${ }^{15}$ have reported that penicillamine induced antiacetylcholine receptor had lower avidity than antiacetylcholine receptor from patients with longstanding idiopathic myasthenia gravis. The inherent limitations mentioned above usually result in curved Scatchard plots when antibody affinity is measured in this way. It is also necessary to remove, or allow for, contaminating IgG from the preparation of acetylcholine receptor if increasing concentrations are to be used (Garlepp et al, unpublished observations). Avidity was said to increase with time of incubation. ${ }^{15}$ Bray and Drachman, ${ }^{16}$ also using Scatchard analysis, but using sera at high dilution and having effectively removed IgG from their preparations of acetylcholine receptor, have reported average affinities of antiacetylcholine receptor in idiopathic myasthenia gravis similar to those reported here. Our data show that antiacetylcholine receptor in patients with penicillamine induced myasthenia gravis was generally of higher average affinity than that from patients with idiopathic disease.

The HLA antigens Bw35 and DR1 were associated with penicillamine induced myasthenia gravis. The increased prevalence of DR1 in patients with penicillamine induced disease has recently been confirmed. ${ }^{17}$ The relative absence of DR4 from the patients with penicillamine induced disease also suggests that these patients are genetically distinct from the remaining patients with rheumatoid arthritis. DR1 has, however, been shown to be increased in patients with rheumatoid arthritis in two different racial groups ${ }^{18}{ }^{19}$ while Bw35 and DR1 may be associated with DR4-negative rheumatoid arthritis in Caucasians (P Kay et al, unpublished observations).

The relative scarcity of $\mathrm{B} 8$ and DR3 in patients with penicillamine induced myasthenia gravis (see also reference 17) contrasts with its increased prevalence in patients with idiopathic myasthenia gravis, particularly in women with early onset. Interestingly $\mathrm{Bw} 35$ and DR1 do influence susceptibility to myasthenia gravis especially in Asian Indians. ${ }^{20}$ Thus one interpretation of our data would be that DR3 and DR4 favour myasthenia gravis and rheumatoid arthritis respectively, whereas the combination of Bw35 and DR1 permits both. Alternatively Bw35 and DR1 may allow a specific reaction with penicillamine or may be a marker for genetic factors affecting immunoregulation. ${ }^{21}$

Some interesting parallels exist. Insulin dependent diabetes mellitus has been shown to be associated with more than one HLA supratype. ${ }^{22}$ Hydralazine induced systemic lupus erythematosus is associated with DR4 although the idiopathic disease is not. ${ }^{23}$
The temporal relationship between administration or withdrawal of penicillamine and onset or remission of disease, the subtle differences in properties of antiacetylcholine receptor, and the distinct HLA association all indicate that penicillamine may induce myasthenia gravis. The demonstration of the association with HLA-Bw35 and DR1 should allow progress in investigation of the mechanisms of induction of antiacetylcholine receptor and myasthenia gravis.

We thank the many clinicians who provided sera and clinical data.

This study was supported by a grant from the National Health and Medical Research Council of Australia. Publication 8252 of the Departments of Clinical Immunology, Perth, Western Australia.

\section{References}

${ }^{1}$ Dawkins RL, Garlepp M, McDonald B, Williamson J, Zilko PJ, Carrano J. Myasthenia gravis and D-Penicillamine. $\mathcal{F}$ Rheumatol $1981 ; 8$, suppl 7 : 169-72.

2 Pirskanen R. On the significance of HL-A and LD antigens in myasthenia gravis. Ann NY Acad Sci 1976;274:451-60.

${ }^{3}$ Dawkins RL. Myasthenia gravis. In: Terasaki PI, ed. Histocompatibility testing 1980. Los Angeles: UCLA Tissue Typing Laboratory, 1980: 662-7.

- Stastny P. Rheumatoid arthritis. In: Terasaki PI, ed. Histocompatibility testing 1980. Los Angeles: UCLA Tissue Typing Laboratory, 1980: $681-6$.

Garlepp MJ, Kay P, Dawkins RL, Bucknall R, Kemp A. Cross-reactivity of anti acetylcholine receptor autoantibodies. Muscle Nerve 1981;4: 282-6.

${ }^{6}$ Garlepp MJ, Christiansen FT, Dawkins RL. Association of HLA BW35, DR1 with D-Penicillamine induced myasthenia gravis. Aust NZ $7 \mathrm{Med}$ $1982 ; \mathbf{1 2 : 5 5 9 .}$

Torres CF, Griggs RC, Baum J, Penn AS. Penicillamine-induced myasthenia gravis in progressive systemic sclerosis. Arthritis Rheum 1980;23:505-8.

* Masters CL, Dawkins RL, Zilko PJ, Simpson JA, Leedman RJ, Lindstrom J. Penicillamine-associated myasthenia gravis: anti acetylcholine receptor and antistriational antibodies. Am F Med 1977;63:689-94.

9 Terasaki PI, ed. Histocompatibility testing 1980. Los Angeles: UCLA Tissue Typing Laboratory, 1980.

10 Russell AS, Lindstrom J. Penicillamine-induced myasthenia gravis associated with antibodies to the acetylcholine receptor. Neurology $1978 ; 28: 847-9$.

11 Albers JW, Hodach RJ, Kimmel DW, Treacey WL. Penicillamineassociated myasthenia gravis. Neurology 1980;30:1246-50.

12 Keesey J, Novom S. HLA antigens in penicillamine-induced myasthenia gravis. Neurology 1979;29:528-9.

13 Garlepp MJ, Kay P, Dawkins RL. The diagnostic significance of autoantibodies to the acetylcholine receptor. Fournal of Neuroimmunology (in press)

14 Odell WD, Abraham GA, Skowsky WR, Hescox MA, Fisher DA Production of antisera for radioimmunoassays. In: Odell WD, Daughaday WH, eds. Principles of competitive binding assays. Philadelphia: Lippincott Co, 1971:57-76.

15 Vincent A, Newsom-Davis J. Acetylcholine receptor antibody characteristics in myasthenia gravis. II. Patients with penicillamine-induced myasthenia or idiopathic myasthenia of recent onset. Clin Exp Immunol 1982;49:266-72.

${ }^{16}$ Bray JJ, Drachman DB. Binding affinities of anti acetylcholine receptor autoantibodies in myasthenia gravis. F Immunol 1982;128:105-10.

1: Delamere JP, Jobson S, Mackintosh LP, Wells L, Walton KW. Penicillamine-induced myasthenia in rheumatoid arthritis: its clinical and genetic features. Ann Rheum Dis (in press).

18 Woodrow JC, Nichol FE, Zaphiropoulos G. DR antigens and rheumatoid arthritis: a study of two populations. $\mathrm{Br}$ Med $\mathcal{F} 1981 ; 283: 1287-8$.

19 Schiff B, Mizrachi Y, Orgad S, Yaron M, Gazit E. Association of HLA AW 31 and HLA-DR1 with adult rheumatoid arthritis. Ann Rheum Dis $1982 ; 41: 403-4$.

2" Mehra NK, Ahuja GK, Vaidya MC. HLA antigen frequencies in myasthenia gravis in North India. In: Dawkins RL, Christiansen FT, Zilko PJ, eds. Immunogenetics in rheumatology. Amsterdam: Excerpta Medica $1982: 264-6$.

"Zilko PJ, Dawkins RL, Holmes K, Witt C. Genetic control of suppressor lymphocyte function in myasthenia gravis: relationship of impaired suppressor function to HLA B8/DR3 and cold reactive lymphocytotoxic antibodies. Clin Immunol Immunopathol 1979;14:222-30.

22. Dawkins RL, Christiansen FT, Kay PH, et al. Disease associations with camplotypes, supratypes and haplotypes. Immunol Rev 1982;70:5-22.

$2: 3$ Batchelor JR, Welsh KI, Tinoco RM, et al. Hydralazine-induced systemic lupus erythematosus: influence of HLA-DR and sex on susceptibility Lancet $1980 ; \mathrm{i}: 1107-9$.

(Accepted 17 November 1982) 